University of Nebraska - Lincoln

DigitalCommons@University of Nebraska - Lincoln

Nebraska Game and Parks Commission -- Staff

Research Publications

Nebraska Game and Parks Commission

6-2013

\title{
Diets and Food Selection of Female Mallards and Blue-Winged Teal During Spring Migration
}

Paul R. Tidwell

Arkansas Tech University \& Advanced Ecology

Elisabeth B. Webb

Arkansas Tech University \& University of Missouri, webbli@missouri.edu

Mark P. Vrtiska

Nebraska Game and Parks Commission, mark.vrtiska@nebraska.gov

Andrew A. Bishop

Rainwater Basin Joint Venture

Follow this and additional works at: https://digitalcommons.unl.edu/nebgamestaff

Tidwell, Paul R.; Webb, Elisabeth B.; Vrtiska, Mark P.; and Bishop, Andrew A., "Diets and Food Selection of Female Mallards and Blue-Winged Teal During Spring Migration" (2013). Nebraska Game and Parks Commission -- Staff Research Publications. 101.

https://digitalcommons.unl.edu/nebgamestaff/101

This Article is brought to you for free and open access by the Nebraska Game and Parks Commission at DigitalCommons@University of Nebraska - Lincoln. It has been accepted for inclusion in Nebraska Game and Parks Commission -- Staff Research Publications by an authorized administrator of DigitalCommons@University of Nebraska - Lincoln. 


\title{
Articles \\ Diets and Food Selection of Female Mallards and Blue-Winged Teal During Spring Migration
}

\author{
Paul R. Tidwell, Elisabeth B. Webb,* Mark P. Vrtiska, Andrew A. Bishop
}

\section{P.R. Tidwell, E.B. Webb}

Department of Biological Sciences, Arkansas Tech University, Russellville, Arkansas 72801

Present address of P.R. Tidwell: Advanced Ecology, Ltd., Center, Texas 75935

Present address of E.B Webb: U.S. Geological Survey, Missouri Cooperative Fish and Wildlife Research Unit, Department of Fisheries and Wildlife Sciences, University of Missouri, Columbia 65211

\section{M.P. Vrtiska}

Nebraska Game and Parks Commission, 2200 N. 33rd Street, Lincoln 68503

\section{A.A. Bishop}

Rainwater Basin Joint Venture, 2550 N. Diers Avenue, Grand Island, Nebraska 68801

\begin{abstract}
Waterfowl nutritional requirements and food availability at migration stopover habitats may differ from those at nesting or wintering areas. Although there is little information on factors that influence waterfowl diets and food selection during migration, we hypothesized that bird age and wetland density in the surrounding landscape would influence food selection. Thus, the objective of this study was to quantify mallard Anas platyrhynchos and blue-winged teal Anas discors diets during migration and evaluate effects of age and wetland density on waterfowl food selection. We collected 30 mallards and 29 blue-winged teal with food items present in esophagi from wetlands in south-central Nebraska during spring 2008 and 2009. Smartweed Polygonum spp. and barnyard grass Echinochloa spp. were the most common seeds found in both mallards and blue-winged teal, while Naididae and Chironomidae larvae were the most common invertebrates in mallard and blue-winged teal diets, respectively. Invertebrates were consumed by both species in greater proportion than available. Both mallards and blue-winged teal collected in wetland complexes selected some seeds over others, whereas birds in isolated wetlands foraged on foods in proportion to availability. After-hatch-year mallards also selected for some seeds over others, as compared with hatch-year birds, which foraged opportunistically on available foods. If after-hatch-year birds and birds in wetland complexes are able to be more selective in their diets relative to food availability at individual wetlands, they may be able to acquire and replenish lipids reserves more efficiently than hatch-year birds or birds in areas with lower wetland densities.
\end{abstract}

Keywords: Anas; blue-winged teal; diet; food selection; mallard; Rainwater Basin; spring migration

Received: July 26, 2012; Accepted: March 18, 2013; Published Online Early: March 2013; Published: June 2013

Citation: Tidwell PR, Webb EB, Vrtiska MP, Bishop AA. 2013. Diets and food selection of female mallards and bluewinged teal during spring migration. Journal of Fish and Wildlife Management 4(1):63-74; e1944-687X. doi: 10.3996/ 072012-JFWM-062

Copyright: All material appearing in the Journal of Fish and Wildlife Management is in the public domain and may be reproduced or copied without permission unless specifically noted with the copyright symbol (C). Citation of the source, as given above, is requested.

The findings and conclusions in this article are those of the author(s) and do not necessarily represent the views of the U.S. Fish and Wildlife Service.

* Corresponding author: webbli@missouri.edu

\section{Introduction}

Waterfowl populations that are widely dispersed on wintering areas can become relatively concentrated at spring migration stopover sites. Consequently, entire populations within a flyway may be affected by habitat quality at migration stopover sites (Myers 1983). Habitat quality influences body condition of many free-living bird species, and several habitat factors at spring stopover sites can influence body condition of migratory 
birds (Krapu 1981; Pattenden and Boag 1989; Bety et al. 2003; Anteau and Afton 2004; DeVries et al. 2008). Food availability at migration stopover sites may differ both quantitatively and qualitatively from food at nesting or wintering areas and, as a result, birds may forage differently during migration (Gauthier et al. 1992). Although several studies have quantified waterfowl diets during spring migration, little is known about waterfowl foraging strategies or food selection during migration (Arzel et al. 2006).

Food availability and selection at spring migration stopovers may be especially important to waterfowl because acquired nutrients could indirectly affect natality rates by delaying the timing of nest initiation and subsequent hatching (Barzen and Serie 1990; Dzus and Clark 1998). If waterfowl arrive on breeding grounds with adequate nutrient reserves, they may nest earlier, and take advantage of the benefits associated with early nesting and hatching dates (Dow and Fredga 1984; Gauthier 1989; Hepp et al. 1989; Dzus and Clark 1998). Waterfowl that do not attain the required nutrient levels may forgo nesting, lay a smaller clutch, or delay nesting until obtaining sufficient nutrient reserves (Barzen and Serie 1990). Therefore, waterfowl food availability and diets at migration stopover sites likely have proximate and ultimate effects on migration chronology, route, and habitat selection (King 1974). To more efficiently manage migration stopover areas, a better understanding of the factors influencing waterfowl diets and food selection during spring migration is needed (Markkola et al. 2003; Arzel and Elmberg 2004).

Diets of many dabbling duck species are dominated by high-energy plant foods during winter, with consumption of protein-rich invertebrates increasing during late spring when egg formation and laying occur (Krapu 1974; Reinecke and Owen 1980; Gammonley 1995; Hohman et al. 1996). Seasonal changes in waterfowl diets have been attributed to varying physiological requirements of waterfowl during different stages of the annual cycle and the relative abundance of food types in specific foraging habitats and seasons. However, few studies have evaluated dabbling duck food selection during migration (although see Hitchcock 2008), and the factors that influence food selection among dabbling ducks at migration stopover sites remain unclear.

Wetland distribution and area are among the landscape-level variables identified as potentially influencing wetland bird habitat use. Landscapes with greater wetland density and area have been positively correlated with waterbird occurrence, abundance, and species richness (Brown and Dinsmore 1986; Webb et al. 2010; Pearse et al. 2012). Although the ecological mechanisms underlying these patterns are unknown, it is thought that birds use areas with multiple wetlands (also known as a wetland complex) that provide a diversity of resources to meet energetic requirements (Brown and Dinsmore 1986; Taft and Haig 2006). Several studies speculated on the potential for wetland area and density within the landscape to influence food availability and foraging efficiency (Farmer and Parent 1997; Webb et al. 2010) and Taft and Haig (2006) reported productive sites with more adjacent wetland habitat had the greatest waterbird use. Farmer and Parent (1997) found that as wetland density increased, shorebirds moved more frequently between feeding sites and hypothesized that less distance between feeding locations allowed birds to exploit more effectively available food resources and simultaneously reduce energy expenditure. A greater abundance and diversity of wetland habitat on the landscape may also minimize negative density-dependent effects resulting from food or habitat limitation (Drent 1996). Moreover, because waterfowl may avoid feeding in areas with scarce resources or dominant competing species (Jeske 1996), wetland complexes may facilitate selective foraging strategies compared with more isolated habitats. Therefore, if wetland landscape metrics influence foraging patterns, we predicted diets of dabbling ducks in areas with greater wetland density would exhibit selection compared with food availability at any one wetland. Conversely, we expected dabbling ducks in areas with lower wetland density would have fewer foraging sites within close proximity and would forage on food items in proportion to availability within a given wetland.

The Rainwater Basin (RWB) region of south-central Nebraska (Figure 1) is an important migration stopover site that provides habitat for 7-10 million waterfowl during spring migration (Bishop and Vrtiska 2008). Wetlands within the RWB serve as a crucial link in the annual migratory journey of wetland birds from wintering areas to breeding grounds (Myers 1983; Bishop and Vrtiska 2008, Webb et al. 2010). Mallards Anas platyrhynchos are among the first waterfowl to arrive in the RWB during spring migration, and are more opportunistic in their feeding strategy than most dabbling duck species (Drilling et al. 2002). Indeed, mallards commonly use a variety of habitats to fulfill dietary requirements, including dry agriculture fields (Jorde et al. 1983). Also, the relatively large physiological structure of mallards enables them to store more lipids than other dabbling ducks (Gloutney and Clark 1991). Blue-winged teal Anas discors (hereafter, teal) typically begin migrating through the RWB later (late March) than mallards, and have less structural capacity to store lipids. As a result, teal may be more susceptible to differences in habitat quality at stopovers, and may compete more intensively for less abundant food resources available later in the migration period. Therefore, we selected mallards and teal as study species to best quantify spring diets for a variety of dabbling ducks and evaluate factors influencing food selection.

Joint Ventures consist of regional partnerships established under the North American Waterfowl Management Plan to help conserve continental waterfowl populations and habitats (Williams et al. 1999; Brasher et al. 2006). The Rainwater Basin Joint Venture (hereafter, RWBJV) recently emphasized production of annual moist-soil plants to help meet energetic requirements of migrating waterfowl (Bishop and Vrtiska 2008). Basic knowledge of foods consumed by migrating waterfowl, specifically dabbling ducks, in RWB wetlands is important for directing conservation and management efforts toward appropriate plant communities. By quantifying diets and factors 


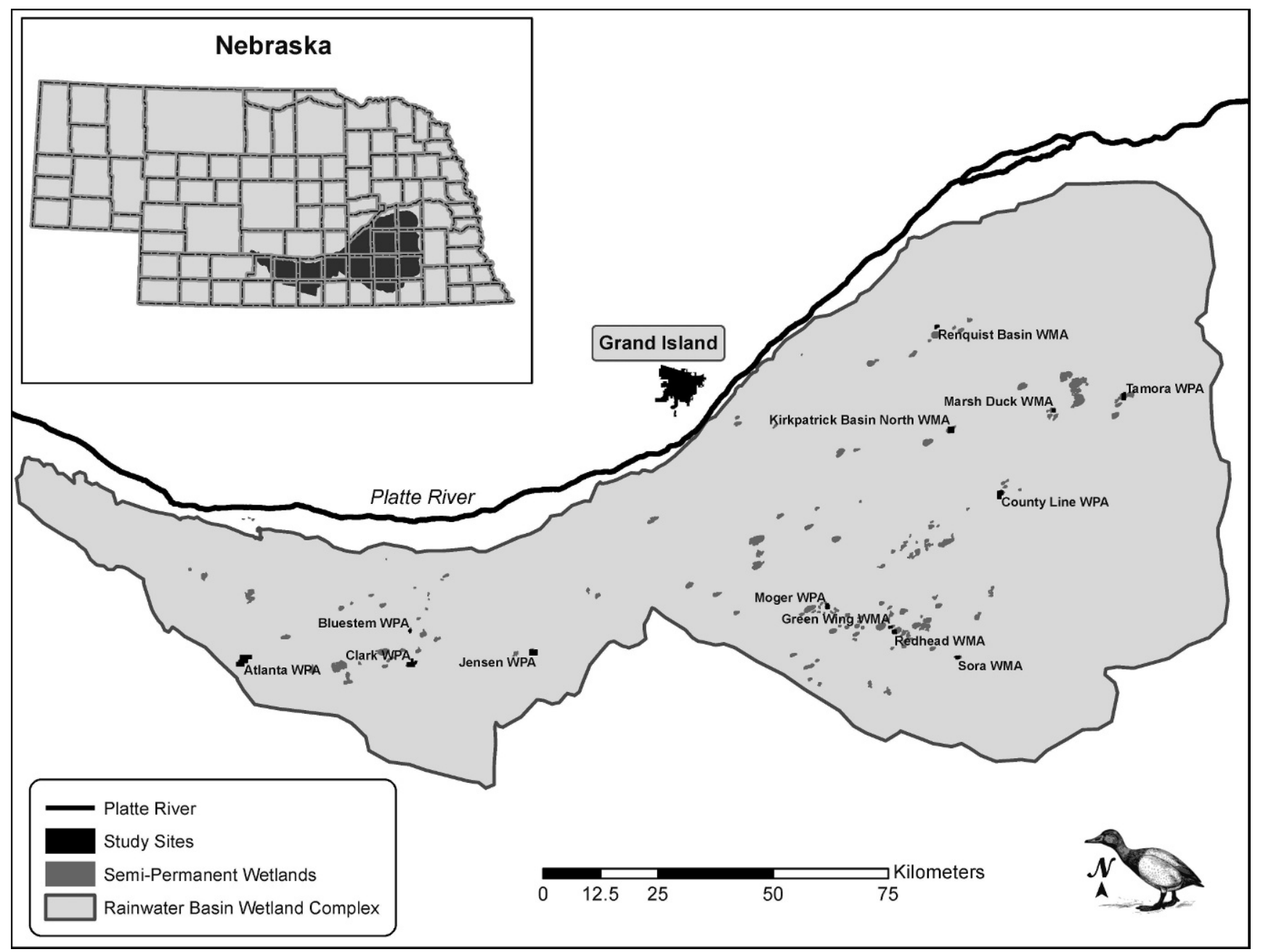

Figure 1. Location of 13 study wetlands in the Rainwater Basin region of Nebraska, where diet and food selection of female mallards Anas platyrhynchos and blue-winged teal A. discors were evaluated in springs 2008 and 2009. All study wetlands were public lands, with Waterfowl Production Areas (WPA) owned and managed by U.S. Fish and Wildlife Service and Wildlife Management Areas (WMA) owned and managed by Nebraska Game and Parks Commission.

influencing food selection for mallards and teal, we may contribute to knowledge of the factors influencing habitat quality for dabbling ducks during migration, which can assist wetland managers in targeting specific habitats for conservation. Therefore, the objectives of this study were to quantify diets and food selection of mallards and teal during spring migration and evaluate effects of age and wetland density on food selection strategies. We hypothesized that dabbling ducks in areas of greater wetland density would be more selective in their diets, whereas ducks collected from isolated wetlands or areas with low wetland density would forage opportunistically and not exhibit food selection. We also hypothesized that adult (or after-hatch-year; AHY) dabbling ducks would have more experience foraging and would be more selective in their diets, compared with juvenile (or hatch-year; HY) dabbling ducks.

\section{Study Area}

Wetlands in the RWB region are classified as playas and distributed among 21 counties in south-central
Nebraska (Figure 1; LaGrange 2005). Playas are small, depressional, freshwater wetlands, occurring in individual watersheds and located throughout the western Great Plains (Smith 2003). The RWB region originally included $>11,000$ natural wetland basins, totaling approximately 80,000 ha (Bishop and Vrtiska 2008). However, conversion of wetlands to agricultural land led to the destruction of $80 \%$ of wetlands and $88 \%$ of original wetland area (Smith and Higgins 1990; LaGrange 2005). The watersheds that funnel water to these wetlands have also been altered significantly (Bishop and Vrtiska 2008) and the remaining wetlands have experienced reductions in area, loss of surface water, and mechanical modifications to facilitate drainage (Smith and Higgins 1990). Wetlands in the RWB are in flat to gently rolling loess plains, located on silt loam or silty clay-loam soils, and range in area from 1 to 16 ha, although several are $>400$ ha (Brennan et al. 2005). Wetlands in the RWB are not recharged through elevated groundwater; therefore, wetland hydrology is largely dependent on seasonal precipitation patterns (Smith 
2003). However irrigation runoff from surrounding agricultural fields and water pumped by natural resource agencies also contribute to the hydrology of some wetlands (Smith 2003; Brennan et al. 2005). Consequently, playa wetland plant communities consist primarily of species adapted to fluctuating wet and dry conditions (Weaver and Bruner 1954; Haukos and Smith 2001).

\section{Methods}

\section{Wetland selection and classification}

We initially identified potential study wetlands using the compiled RWBJV aerial habitat surveys (A. Bishop, RWBJV, unpublished data). These surveys were collected in a geospatial environment and conducted from 2004 through spring 2007. To minimize biases associated with hydrology and potential disturbance (i.e., open to Light Goose Conservation Order activities [U.S. Fish and Wildlife Service 2007; Webb et al. 2011]), we limited potential study sites to wetlands open to public hunting and in which $\geq 25 \%$ of the hydric soil footprint was classified as semipermanent (Cowardin et al. 1979). We used Earth Resources Data Analysis System (ERDAS 1999) modeler to determine total number of all functioning wetlands (exhibited ponded water and/or hydrophytic vegetation) within a $10-\mathrm{km}$ radius of each potential study wetland. We used a $10-\mathrm{km}$ radius surrounding each potential study wetland because it included the range of foraging flight distances for dabbling ducks in the RWB (Pearse et al. 2011), and because previous research reported wetland landscape variables within $10 \mathrm{~km}$ positively influenced dabbling duck abundance (Webb et al. 2010). Number of functioning wetlands differed with annual precipitation; therefore, we quantified functioning wetland density within $10 \mathrm{~km}$ by year. After determining landscape wetland density for each potential study wetland, we selected study sites across the geographic range of RWB wetlands and across the gradient of wetland density on the landscape. Throughout the RWB, wetland density within $10-\mathrm{km}$ radius of individual wetlands ranged from 0.038 to 0.541 wetlands $/ \mathrm{km}^{2}(12-170$ wetlands within the $10-\mathrm{km}$ buffer). We determined median wetland density among all potential study wetlands and used this number to classify study wetlands into two groups based on surrounding wetland density; wetlands below the median were classified as "low density" wetlands (12-51 wetlands within $10 \mathrm{~km} ; n=11$ ), and wetlands above the median were considered "high density" wetlands (58-170 wetlands within $10 \mathrm{~km} ; n=7$ ).

We also attempted to select study wetlands with similar area and vegetative cover. However, due to variation in annual precipitation patterns, wetland area and percent vegetative cover varied between and within years. As a result, we selected sample wetlands on an opportunistic basis; and absence of high-density wetlands in the western half of the RWB prevented us from selecting an equal number of wetlands from eastern and western basins.

\section{Data collection}

We collected female mallards and teal from 13 study wetlands throughout spring migration (late February to early April for mallards and late March to early May for teal) in 2008 and 2009. To help ensure the presence of esophageal contents in each bird, we observed foraging activity from an unobtrusive vantage point and attempted to collect individuals that fed for a minimum of 10 minutes (Gammonley 1995). However, when vantage points were obstructed by vegetation and/or topography, we confirmed feeding activity of birds in the immediate vicinity and moved toward the observed group until birds began flushing. We approached observed birds and collected the first female to flush in range suitable for collection by shotgun. After successful collections, we determined age (AHY or HY) by wing plumage characteristics (Carney 1992). Before additional collection attempts at the same study wetland, we allowed wetlands to rest for approximately $1 \mathrm{wk}$ or until density of target species permitted further sampling.

Following successful collection attempts, we injected $75 \%$ ethanol into the esophagus of each bird to minimize postmortem digestion of esophagus contents (Bailey and Titman 1984) and placed birds over ice in a cooler until they could be frozen. On average, birds were processed within 15 min of sampling; however, no longer than 25 min elapsed between sampling and ethanol injections for all birds. We stored birds at $-10^{\circ} \mathrm{C}$ until they could be processed, at which time we thawed them, and washed the contents of esophagus and proventriculus (hereafter, esophagus) from each bird through $0.5-\mathrm{mm}$ and $2.0-\mathrm{mm}$ sieves (Davis and Smith 1998). We identified plant seeds to genus (Martin and Barkley 1973; Legagneux et al. 2007; US Department of Agriculture 2009) and invertebrates to Order and, when possible, to Family (Pennak 1989; Merritt and Cummins 1996). Birds with <5 food items present in their esophagi were considered to have not actively fed and were excluded from analyses (Reinecke and Owen 1980). We noted agricultural grains, if present, but because our study objectives focused on wetland foods, we did not include agricultural grains in quantifying diets or calculating food selection within wetland habitats. We dried seeds and invertebrates at $60^{\circ} \mathrm{C}$ for a minimum of $24 \mathrm{~h}$ and weighed each food item to the nearest $0.1 \mathrm{mg}$. We expressed food use as percent occurrence and aggregate percent dry mass (Swanson et al. 1974a; Anderson et al. 2000).

Immediately following successful bird collection, we collected food availability data along a linear transect within the portion of the wetland where most birds were observed feeding. Thus, wetland food availability was assessed at the same general time and location that each bird was collected. Availability samples consisted of 5 benthic cores $(5 \times 10 \mathrm{~cm})$ and 5 sweep samples $\left(1 \mathrm{~m}^{2}\right.$; $92.7 \mathrm{~L}$ ) located randomly along a 30-m transect (DuBowy 1988). We placed core and sweep samples in separate plastic bags marked with specific bird identification labels, and stored them over ice until they could be frozen for processing at a later date. In the laboratory, we thawed and soaked each core sample in a 3\% hydrogen peroxide solution $\left(\mathrm{H}_{2} \mathrm{O}_{2}\right)$, washed contents through 0.5 $\mathrm{mm}$ and $2.0-\mathrm{mm}$ sieves to separate samples into coarse and fine vegetative matter, and dried to a constant mass at approximately $60^{\circ} \mathrm{C}$ for a minimum of $24 \mathrm{~h}$ (Kross et al. 
2008; Hagy and Kaminski 2012). We recovered larger seeds (from the 2-mm sieve) through visual inspection and used a $\times 1.5$ magnifying lens and light source to recover smaller seeds (from the $0.5-\mathrm{mm}$ sieve; Olmstead et al. 2013), which we identified to genus (Martin and Barkley 1973; Legagneux et al. 2007; U.S. Department of Agriculture 2009). We estimated invertebrate availability by removing invertebrates from vegetative debris using forceps and identified to them to Order or, when possible, Family (Pennak 1989; Merritt and Cummins 1996). Seed and invertebrate availability samples were dried to a constant mass at $60^{\circ} \mathrm{C}$ for $24 \mathrm{~h}$ and weighed to the nearest $0.1 \mathrm{mg}$ separately by taxonomic group. Following processing, we combined invertebrate and seed biomass estimates from benthic and water column samples to estimate total food availability for each bird collected (Anderson et al. 2000).

\section{Statistical analysis}

To determine food selection between wetland density and age categories, we compared use and availability of food items using Johnson's (1980) method based on rank comparison, which was appropriate for these data (Alldredge and Griswold 2006). We selected this method of comparing use and availability data because it is relatively insensitive to the inclusion of questionable food items (or where determination of "true" availability is not straightforward) and results in an ordering of food items that allows relative statements of selection (Johnson 1980; Alldredge and Griswold 2006). We obtained aggregate percent dry biomass of food items recovered from individual birds and compared these with aggregate percent dry biomass of available food items in the wetland where each bird was collected. We ranked percent biomass of each food item within each bird and within each wetland and calculated the differences in ranked use and ranked availability for each food item for each bird. We tested three hypotheses using rank comparison: 1) percent mass of total seeds and invertebrates were consumed by birds in proportion to their availability, 2) percent mass of individual seed genera were consumed in proportion to availability, and 3) percent mass of individual invertebrate families were consumed in proportion to availability.

We used multivariate analysis of variance (MANOVA) to test the above hypotheses that use and availability rank differences varied between age and wetland density categories, with the null hypothesis that selection for all food items was equal to zero (Johnson 1980). Hotelling's $T^{2}$ was used to evaluate these hypotheses and we used the corresponding $F$ statistic to test the null hypothesis. Following a significant MANOVA ( $P \leq 0.05$ ), we used a Waller-Duncan multiple-comparison procedure (Waller and Duncan 1969) to determine whether selection differed among food items, as recommended by Johnson (1980). We established a K-value of 100 (which is analogous to $\alpha=0.05$; Waller and Duncan 1969) and calculated a minimum value for mean use-availability rank differences (which, if exceeded, indicated a significant difference in selection of two food items; Johnson 1980).

\section{Results}

We collected 60 mallards and 117 teal from 13 wetlands during springs 2008 and 2009. Mean ( \pm SE) functional area of study wetlands was $90( \pm 11.5)$ ha and, on average, $36 \%$ of the functional wetland area consisted of soils classified as semipermanent hydric soils. Among all birds collected, 30 mallards and 29 teal had food items present in esophagi; therefore, all diet analyses were performed on these individuals. In 2008, we obtained use and availability samples for 22 mallards (16 AHY and $6 \mathrm{HY}$ ) from 4 March to 2 April and 17 teal (12 AHY and $5 \mathrm{HY}$ ) from 31 March to 6 May. In 2009, we obtained use and availability samples for 8 mallards (2 AHY and $6 \mathrm{HY}$ ) from 25 February to 1 April and 12 teal (7 AHY and $5 \mathrm{HY}$ ) from 26 March to 6 May.

Mallard diets of wetland foods during spring migration consisted of $65 \%$ seeds and $35 \%$ invertebrates, based on aggregate dry mass (Table 1; Table S1, Supplemental Material). The most commonly occurring food items in mallard diets were smartweed Polygonum spp. seeds, found in $67 \%$ of birds and consisting of approximately $31 \%$ of total dry mass of wetland foods consumed. Naididae were the most common invertebrate food item found in mallard diets and comprised $20 \%$ of total dry mass of all consumed wetland food items. Teal wetland food diets consisted of $64 \%$ seeds and $36 \%$ invertebrates, based on aggregate dry mass (Table 1; Table S2, Supplemental Material). Smartweed seeds were the most common wetland food item detected in teal diets and accounted for $31 \%$ of the total dry biomass. Planorbidae were the most commonly recovered invertebrate food item in teal diets; however, Chironomidae represented the greatest percent of diet biomass (13\%). Although we did not include agricultural grains found in birds to evaluate diet or selection, we noted corn kernels present in $27 \%$ of mallards and $7 \%$ of teal.

Mallard wetland foods were not consumed in proportion to availability by age $(F \geq 5.50, P \leq 0.038)$ or wetland density category ( $F \geq 5.33, P \leq 0.039)$. Mallards in both age groups and density categories consumed invertebrates in greater proportion than their availability and consumed seeds less than expected based on availability (Tables 2 and 3; Table S3, Supplemental Material). Mallards collected in high-density wetlands did not consume seed genera in proportion to availability $(F=5.13, P=0.013)$. Specifically, birds from highdensity wetlands consumed cutgrass Leersia spp. more than was available and smartweed less than available (Table 2). However, birds collected from high-density wetlands consumed invertebrate families in proportion to availability ( $F=1.61, P=0.23$; Table 2$)$. Mallards from low-density wetlands foraged on individual wetland food items in proportion to availability $(F=0.60, P=0.71)$ and did not exhibit selection among seeds $(F=1.10$, $P=0.40)$ or invertebrates $(F=0.81, P=0.52)$. Afterhatch-year mallards selected for cutgrass and barnyard grass Echinochloa spp. and against smartweed $(F=4.39$, $P=0.021$ ) but consumed invertebrate families in proportion to availability ( $F=0.95, P=0.44$; Table 3 ). Hatch-year mallards did not exhibit selection for or 
Table 1. Percent occurrence and aggregate dry mass of wetland food items ingested by female mallards Anas platyrhynchos $(n=30)$ and blue-winged teal A. discors $(n=$ 29) collected from wetlands in the Rainwater Basin of Nebraska, during spring migrations 2008 and 2009.

\begin{tabular}{|c|c|c|c|}
\hline Species & Food item ${ }^{a}$ & Occurrence & $\begin{array}{l}\text { Aggregate } \\
\text { dry biomass }\end{array}$ \\
\hline \multirow[t]{15}{*}{ Mallards } & Seeds & 83.3 & 65.4 \\
\hline & Echinochloa spp. & 33.3 & 15.0 \\
\hline & Eleocharis spp. & 3.3 & $\operatorname{Tr}^{\mathrm{b}}$ \\
\hline & Leersia spp. & 16.7 & 9.0 \\
\hline & Helianthus spp. & 3.3 & 0.3 \\
\hline & Polygonum spp. & 66.8 & 30.9 \\
\hline & Potomogeton spp. & 6.8 & 6.3 \\
\hline & Sparganium spp. & 10.0 & 4.0 \\
\hline & Animal matter & 40.0 & 34.6 \\
\hline & Chironomidae & 3.3 & 2.0 \\
\hline & Lymnaeidae & 3.3 & 2.6 \\
\hline & Naididae & 30.0 & 20.1 \\
\hline & Notonectidae & 3.3 & 0.5 \\
\hline & Planorbidae & 13.3 & 4.2 \\
\hline & Physidae & 20.0 & 5.3 \\
\hline \multirow[t]{16}{*}{ Blue-winged teal } & Seeds & 93.3 & 64.3 \\
\hline & Carex spp. & 3.3 & 1.1 \\
\hline & Cyperus spp. & 3.3 & 1.8 \\
\hline & Echinochloa spp. & 36.7 & 15.9 \\
\hline & Eleocharis spp. & 3.3 & 2.9 \\
\hline & Leersia spp. & 10.0 & 6.6 \\
\hline & Polygonum spp. & 63.3 & 31.2 \\
\hline & Potomogeton spp. & 6.7 & 4.8 \\
\hline & Animal matter & 64.3 & 35.7 \\
\hline & Chironomidae & 26.7 & 13.4 \\
\hline & Corixidae & 6.7 & 1.4 \\
\hline & Gammaridae & 3.3 & 0.6 \\
\hline & Lymnaeidae & 6.7 & 1.0 \\
\hline & Planorbidae & 30.0 & 5.9 \\
\hline & Physidae & 20.0 & 7.4 \\
\hline & Sphaeriidae & 13.3 & 6.1 \\
\hline
\end{tabular}

a Although agricultural waste grains were detected in $27 \%$ of mallards and $7 \%$ of teal, we did not include agricultural grains in quantifying diets. Thus, percent aggregate biomass estimates were based exclusively on wetland food items consumed by birds.

${ }^{b}$ Trace amount $(<0.1 \%)$.

against specific seeds $(F=3.28, P=0.07)$ or invertebrates $(F=2.72, P=0.11)$.

Teal did not consume wetland foods in proportion to availability by age $(F \geq 4.80, P \leq 0.04)$ or wetland density category $(F \geq 5.20, P \leq 0.04)$. Teal from both age groups and density categories consumed invertebrates in greater proportion than their availability and consumed seeds less than expected based on availability (Tables 4 and 5; Table S4, Supplemental Material). Teal collected from highdensity wetlands did not consume food items in proportion to availability $(F=4.30, P=0.03)$, whereas teal from low-density wetlands consumed foods in proportion to availability ( $F=1.99, P=0.17$ ). Birds collected in high-density wetlands selected for cutgrass and against smartweed ( $F=3.13, P=0.006$; Table 4). After-hatch-year teal selected individual wetland food items in proportion to availability; however, HY teal selected for cutgrass and barnyard grass, and against smartweed $(F=10.79, P=0.005)$. Hatch-year teal were also selective among invertebrate food items $(F=2.98, P$ $=0.04$ ), selecting for Chironomidae and against Sphaeriidae (Table 5).

\section{Discussion}

Dabbling duck diets vary seasonally in response to nutritional requirements based on life-history stage, including molt, breeding, and migration, as well as to spatial and temporal food availability (Gruenhagen and Fredrickson 1990; Krapu and Reinecke 1992; Anderson et al. 2000). Previous studies reported diets of mallards collected from moist-soil habitats during spring migration contained as little as $2 \%$ invertebrates (Gruenhagen and Fredrickson 1990) and up to $72 \%$ animal matter in diets of mallards breeding in North Dakota (Swanson et al. 1985). Hitchcock (2008) quantified mallard diets during spring migration and reported that invertebrates comprised $28 \%$ of diets for birds that had begun rapidfollicular development, compared with $16 \%$ of diets of birds that had not begun rapid-follicular development. Although we did not assess rapid-follicular development, our estimate of $35 \%$ animal matter in mallard diets greatly exceeds the amount of animal matter reported present in wintering dabbling ducks diets (range of 110\%; Jorde et al. 1983; Delnicki and Reinecke 1986; Miller et al. 2009) and suggests that mallards may be increasing invertebrate consumption before arrival on the nesting areas. It is important to note that because we quantified only food items found in wetlands and excluded agricultural waste grains from estimates of percent biomass in diets, caution should be used in comparing our results with other studies that include waste grains in assessing waterfowl diets. However, when we quantified diets of mallards with only wetland foods (no waste grains) present in their diet (73\% of total sample size), we detected a similar percentage of invertebrates (38\%); this led us to conclude that invertebrates are an important dietary component for spring migrating dabbling ducks.

Although teal forage opportunistically on a diversity of aquatic invertebrates, seeds, aquatic plants, and occasionally agricultural grains throughout most of the year (Rowher et al. 2002), diet composition during nesting is generally dominated by invertebrates (Swanson et al. 1974b; Swanson and Meyer 1977). Among studies that quantified female teal diets during spring migration, invertebrate consumption ranged from $58 \%$ in the Great Lakes region (Hitchcock 2008) to $65 \%$ in seasonally flooded impoundments in southern Missouri (Taylor 1978). Moreover, invertebrate matter in teal diets was reported as high as $86 \%$ among unpaired males in Louisiana (Manley et al. 1992). Compared with previous studies, we found a lower percentage of invertebrates 
Table 2. Food use (aggregate $\%$ dry mass in diet), food availability (aggregate $\%$ dry mass in wetlands), and food selection for mallards Anas platyrhynchos by wetland density category (high and low) collected from 13 wetlands in the Rainwater Basin of Nebraska, March-May 2008 and 2009.

\begin{tabular}{|c|c|c|c|c|c|c|c|}
\hline \multirow[b]{3}{*}{ Test } & \multirow[b]{3}{*}{ Food } & \multicolumn{6}{|c|}{ Aggregate \% } \\
\hline & & \multicolumn{2}{|c|}{ Use } & \multicolumn{2}{|c|}{ Available } & \multicolumn{2}{|c|}{$t_{i j}^{a}$} \\
\hline & & High $(n=17)$ & Low $(n=13)$ & High & Low & High & Low \\
\hline \multirow[t]{2}{*}{ Test 1 (seeds vs. invertebrates) } & Seeds & 67.7 & 68.8 & 85.5 & 95.8 & $0.29 \mathrm{~A}^{\mathrm{b}}$ & $0.31 \mathrm{~A}$ \\
\hline & Invertebrates & 32.3 & 31.2 & 14.5 & 4.2 & $-0.29 \mathrm{~B}$ & $-0.31 \mathrm{~B}$ \\
\hline \multirow[t]{3}{*}{ Test 2 (within seeds) } & Echinochloa spp. & 16.9 & 19.8 & 14.4 & 24.4 & $0.47 \mathrm{AB}$ & $0.46 \mathrm{~A}$ \\
\hline & Leersia spp. & 15.8 & 1.5 & 2.4 & 0.9 & $-0.56 \mathrm{~A}$ & $-0.08 \mathrm{~A}$ \\
\hline & Polygonum spp. & 38.1 & 40.6 & 75.5 & 60.8 & $1.47 \mathrm{~B}$ & $0.81 \mathrm{~A}$ \\
\hline \multirow[t]{3}{*}{ Test 3 (within invertebrates) } & Naididae & 20.7 & 26.1 & 2.6 & 3.3 & $-0.88 \mathrm{~A}$ & $-1.00 \mathrm{~A}$ \\
\hline & Planorbidae & 5.9 & 2.9 & 4.6 & 6.9 & $-0.26 \mathrm{~A}$ & $-0.12 \mathrm{~A}$ \\
\hline & Physidae & 2.6 & 9.1 & 0.6 & 3.8 & $-0.24 \mathrm{~A}$ & $-0.08 \mathrm{~A}$ \\
\hline
\end{tabular}

a Selection was estimated following Johnson's (1980) rank comparison method, where $t_{i j}$ is the mean difference in rank of use and rank of availability for each food item. A negative sign for $t_{i j}$ indicates use exceeded availability and a positive value indicates use was less than availability.

b Means followed by the same letter within a "test" do not differ $(P>0.05)$, based on the Waller-Duncan multiple-comparison test.

(36\%) in teal diets, whereas invertebrate availability for teal ranged from 4 to $15 \%$ of total available wetland foods at our study sites.

Few studies have evaluated food selection for nonbreeding dabbling ducks (Callicutt et al. 2011) and prior to this study, no compelling evidence of food selection was available for female mallards or teal during spring migration (Drilling et al. 2002; Rowher et al. 2002). We reported a consistent pattern of both species selecting invertebrates disproportionate to availability, regardless of age or wetland density categories in which birds were collected. Although birds foraged on invertebrates disproportionate to their availability, we did not detect selection for any invertebrate family over others; this led us to conclude that while overall invertebrates may be an important dietary component for spring migrating dabbling ducks, presence and abundance of individual taxa is less important. Additionally, low invertebrate availability in wetlands during early spring
(Gordon et al. 1990) may have precluded selection among individual taxa and encouraged opportunistic consumption of all invertebrates encountered.

Previous researchers hypothesized that wetland birds depend upon a diversity of habitats for various lifehistory requirements and landscapes with greater wetland density were more likely to include a diversity of wetland types that would allow birds to be more selective in their food choices (Brown and Dinsmore 1986; LaGrange and Dinsmore 1988; Fairbairn and Dinsmore 2001; Webb et al. 2010). We found both mallards and teal collected in areas with high wetland density selected some seed genera over others. Our results support the hypothesis that wetland density within the landscape likely increases waterfowl access to a diversity of habitat types, which allowed birds to select specific seeds and potentially meet various nutritional requirements more efficiently. Indeed, in more isolated wetlands, birds may have been increasingly subject to

Table 3. Food use (aggregate \% dry mass in diet), food availability (aggregate \% dry mass in wetlands), and food selection for mallards Anas platyrhynchos by age (after-hatch-year [AHY] and hatch-year [HY]) collected from 13 wetlands in the Rainwater Basin of Nebraska, March-May 2008 and 2009.

\begin{tabular}{|c|c|c|c|c|c|c|c|}
\hline \multirow[b]{3}{*}{ Test } & \multirow[b]{3}{*}{ Food } & \multicolumn{6}{|c|}{ Aggregate \% } \\
\hline & & \multicolumn{2}{|c|}{ Use } & \multicolumn{2}{|c|}{ Available } & \multicolumn{2}{|c|}{$t_{i j}^{a}$} \\
\hline & & AHY $(n=18)$ & HY $(n=12)$ & AHY & HY & AHY & HY \\
\hline \multirow[t]{2}{*}{ Test 1 (seeds vs. invertebrates) } & Seeds & 73.7 & 59.9 & 95.9 & 81.2 & $0.28 \mathrm{~A}^{\mathrm{b}}$ & $0.33 \mathrm{~A}$ \\
\hline & Invertebrates & 26.3 & 40.1 & 4.1 & 18.8 & $-0.28 \mathrm{~B}$ & $-0.33 \mathrm{~B}$ \\
\hline \multirow[t]{3}{*}{ Test 2 (within seeds) } & Echinochloa spp. & 23.7 & 9.1 & 17.0 & 21.9 & $0.11 \mathrm{~A}$ & $1.00 \mathrm{~A}$ \\
\hline & Leersia spp. & 15.1 & 0.0 & 1.7 & 1.6 & $-0.61 \mathrm{~A}$ & $0.04 \mathrm{~A}$ \\
\hline & Polygonum spp. & 27.6 & 58.2 & 70.9 & 65.6 & $1.31 \mathrm{~B}$ & $1.00 \mathrm{~A}$ \\
\hline \multirow[t]{3}{*}{ Test 3 (within invertebrates) } & Naididae & 24.9 & 20.2 & 2.6 & 3.4 & $-0.78 \mathrm{~A}$ & $-1.17 \mathrm{~A}$ \\
\hline & Planorbidae & 2.2 & 8.5 & 7.2 & 3.0 & $0.22 \mathrm{~A}$ & $-0.83 \mathrm{~A}$ \\
\hline & Physidae & 6.5 & 3.9 & 0.6 & 4.4 & $-0.25 \mathrm{~A}$ & $-0.04 \mathrm{~A}$ \\
\hline
\end{tabular}

a Selection was estimated following Johnson's (1980) rank comparison method, where $t_{i j}$ is the mean difference in rank of use and rank of availability for each food item. A negative sign for $t_{i j}$ indicates use exceeded availability and a positive value indicates use was less than availability.

b Means followed by the same letter within a "test" do not differ $(P>0.05)$, based on the Waller-Duncan multiple-comparison test. 
Table 4. Food use (aggregate \% dry mass in diet), food availability (aggregate \% dry mass in wetlands), and food selection by blue-winged teal Anas discors by wetland density category (high and low) collected from 13 wetlands in the Rainwater Basin of Nebraska, March-May 2008 and 2009.

\begin{tabular}{|c|c|c|c|c|c|c|c|}
\hline \multirow[b]{3}{*}{ Test } & \multirow[b]{3}{*}{ Food } & \multicolumn{6}{|c|}{ Aggregate \% } \\
\hline & & \multicolumn{2}{|c|}{ Use } & \multicolumn{2}{|c|}{ Available } & \multicolumn{2}{|c|}{$t_{i j}^{a}$} \\
\hline & & High $(n=14)$ & Low $(n=15)$ & High & Low & High & Low \\
\hline \multirow[t]{2}{*}{ Test 1 (seeds vs. invertebrates) } & Seeds & 61.5 & 64.7 & 93.4 & 87.6 & $0.36 \mathrm{~A}^{\mathrm{b}}$ & $0.29 \mathrm{~A}$ \\
\hline & Invertebrates & 38.5 & 35.3 & 6.6 & 12.4 & $-0.36 \mathrm{~B}$ & $-0.29 \mathrm{~B}$ \\
\hline \multirow[t]{3}{*}{ Test 2 (within seeds) } & Echinochloa spp. & 15.4 & 20.9 & 14.0 & 12.4 & $0.14 \mathrm{~A}$ & $-0.10 \mathrm{~A}$ \\
\hline & Leersia spp. & 14.3 & 0.0 & 2.7 & 0.0 & $0.25 \mathrm{~A}$ & $-0.13 \mathrm{~A}$ \\
\hline & Polygonum spp. & 22.5 & 40.3 & 73.8 & 70.1 & $-2.46 \mathrm{~B}$ & $0.90 \mathrm{~A}$ \\
\hline \multirow[t]{4}{*}{ Test 3 (within invertebrates) } & Chironomidae & 16.6 & 17.6 & 1.0 & 0.8 & $-0.68 \mathrm{~A}$ & $-0.60 \mathrm{~A}$ \\
\hline & Planorbidae & 15.2 & 8.6 & 4.9 & 8.7 & $-1.07 \mathrm{~A}$ & $0.30 \mathrm{~A}$ \\
\hline & Physidae & 11.1 & 5.4 & 2.8 & 8.0 & $-0.43 \mathrm{~A}$ & $-0.03 \mathrm{~A}$ \\
\hline & Sphaeriidae & 5.0 & 0.4 & 0.9 & 0.0 & $-0.18 \mathrm{~A}$ & $-0.33 \mathrm{~A}$ \\
\hline
\end{tabular}

a Selection was estimated following Johnson's (1980) rank comparison method, where $t_{i j}$ is the mean difference in rank of use and rank of availability for each food item. A negative sign for $t_{i j}$ indicates use exceeded availability and a positive value indicates use was less than availability.

b Means followed by the same letter within a "test" do not differ $(P>0.05)$, based on the Waller-Duncan multiple-comparison test.

variations in habitat quality of individual wetlands and not been as likely to select high-quality food items or use wetlands within the landscape as foraging sites. Farmer and Parent (1997) reported that as wetland density increased, shorebirds moved more frequently between feeding sites, and they hypothesized that less distance between feeding locations allowed birds to more effectively exploit available food resources while reducing search costs. If birds in high-wetland-density landscapes are simultaneously able to select preferred food items and reduce energetic costs associated with traveling to other feeding sites, it may result in greater nutrient acquisition rates and lipid reserves, as well as overall better body condition for spring migrating dabbling ducks (Tidwell 2010).

Although we detected selection among food items for HY teal, our results may have been confounded by challenges in differentiating between $\mathrm{HY}$ and $\mathrm{AHY}$ teal, due to possible similarities in plumage characteristics in late spring. However, we found that AHY mallards selected certain seeds disproportionate to their availability, which supports previous research indicating AHY waterfowl often forage more efficiently than juveniles (McLandress and Raveling 1981; Heitmeyer 1988; Gammonley and Heitmeyer 1990). Therefore, it is likely that the efficiency with which individuals use wetland complex habitats may increase with age and experience. Indeed, AHY of both species collected from high-density wetlands had greater lipid mass, whereas lipid mass of HY birds was not influenced by landscape-level characteristics (Tidwell 2010). The interaction between wetland density and age suggests that AHY birds with more foraging experience may be able to exploit habitats that allow them to acquire greater lipid reserves or acquire

Table 5. Food use (aggregate $\%$ dry mass in diet), food availability (aggregate $\%$ dry mass in wetlands), and food selection for blue-winged teal Anas discors by age (after-hatch-year [AHY] and hatch-year [HY]) collected from 13 wetlands in the Rainwater Basin of Nebraska, March-May 2008 and 2009.

\begin{tabular}{|c|c|c|c|c|c|c|c|}
\hline \multirow[b]{3}{*}{ Test } & \multirow[b]{3}{*}{ Food } & \multicolumn{6}{|c|}{ Aggregate \% } \\
\hline & & \multicolumn{2}{|c|}{ Use } & \multicolumn{2}{|c|}{ Available } & \multicolumn{2}{|c|}{$t_{i j}{ }^{a}$} \\
\hline & & AHY $(n=19)$ & HY $(n=10)$ & AHY & HY & AHY & HY \\
\hline \multirow[t]{2}{*}{ Test 1 (seeds vs. invertebrates) } & Seeds & 71.4 & 45.3 & 89.6 & 92.3 & $0.21 \mathrm{~A}^{\mathrm{b}}$ & $0.55 \mathrm{~A}$ \\
\hline & Invertebrates & 28.6 & 54.7 & 10.4 & 7.3 & $-0.21 B$ & $-0.55 \mathrm{~B}$ \\
\hline \multirow[t]{3}{*}{ Test 2 (within seeds) } & Echinochloa spp. & 18.8 & 19.1 & 12.3 & 14.8 & $-0.18 \mathrm{~A}$ & $0.40 \mathrm{~A}$ \\
\hline & Leersia spp. & 5.3 & 11.1 & 2.0 & 0.0 & $-0.03 \mathrm{~A}$ & $-0.50 \mathrm{~A}$ \\
\hline & Polygonum spp. & 42.3 & 13.0 & 69.9 & 75.6 & $1.00 \mathrm{~A}$ & $2.90 \mathrm{~B}$ \\
\hline \multirow[t]{4}{*}{ Test 3 (within invertebrates) } & Chironomidae & 10.3 & 33.3 & 0.8 & 1.0 & $-0.16 \mathrm{~A}$ & $-1.55 \mathrm{~A}$ \\
\hline & Planorbidae & 8.7 & 19.5 & 10.5 & 0.0 & $0.18 \mathrm{~A}$ & $-1.40 \mathrm{AB}$ \\
\hline & Physidae & 10.6 & 4.0 & 4.5 & 7.4 & $-0.32 \mathrm{~A}$ & $-0.05 A B$ \\
\hline & Sphaeriidae & 4.0 & 0.0 & 0.0 & 1.3 & $-0.50 \mathrm{~A}$ & $0.20 \mathrm{~B}$ \\
\hline
\end{tabular}

a Selection was estimated following Johnson's (1980) rank comparison method, where $t_{i j}$ is the mean difference in rank of use and rank of availability for each food item. A negative sign for $t_{i j}$ indicates use exceeded availability and a positive value indicates use was less than availability.

b Means followed by the same letter within a "test" do not differ $(P>0.05)$, based on the Waller-Duncan multiple-comparison test. 
lipid reserves more efficiently. Although birds in both age groups and wetland density categories used smartweed less than available, these seeds were also the most frequently occurring diet items detected and made up the largest proportion of diets for both species. This discrepancy may be the result of combining four species in the same smartweed genus into one category, which could potentially have masked selection for or against any one of the smartweed species. Another potential explanation for the apparent selection against smartweed could be that birds reached a "threshold" of smartweed consumption and did not need to consume more, even if a greater proportion of smartweed was available. Finally, selection against smartweed and for either cutgrass or barnyard grass may have been based on differences in total metabolizable energy of the seed species, with cutgrass and barnyard grass containing as much as three times more metabolizable energy than was found in smartweed (Hoffman and Bookhout 1985; Checkett et al. 2002).

\section{Management Implications}

The primary focus of wetland management at migration stopover sites has been availability of moistsoil seeds and waste grains based on bioenergetic needs of dabbling ducks during spring migration (Bishop and Vrtiska 2008). However, invertebrates may warrant increased management efforts at migration stopover sites and implementing wetland management techniques that simultaneously increase moist-soil seed and invertebrate availability will likely allow birds to increase invertebrate consumption during spring migration (Davis and Bidwell 2008). In addition to active management, longer hydroperiods of managed wetlands often result in greater invertebrate biomass (Anderson and Smith 2000) and may allow more invertebrates to overwinter and be available earlier in the spring compared with unmanaged wetlands or wetlands whose hydrology has been altered (Murkin and Ross 1999). Our results emphasize the importance of landscape-level factors at migration stopover sites and indicate that conservation efforts that focus on wetland habitats with greater surrounding wetland density may increase overall habitat quality for dabbling ducks during spring migration. By restoring groups of wetlands with varying hydrology and area, as well as managing for wetland complexes, there is a greater likelihood that in any given year wetlands with suitable hydrology and vegetative conditions will be present to meet the energetic needs of the greatest diversity of waterbirds (Fairbairn and Dinsmore 2001).

\section{Supplemental Material}

Please note: The Journal of Fish and Wildlife Management is not responsible for the content or functionality of any supplemental material. Queries should be directed to the corresponding author for the article.

Table S1. Mallard Anas platyrhynchos diet data (based on percent dry biomass) for birds collected during springs 2008 and 2009 in the Rainwater Basin of
Nebraska. Data include Bird Number (individual bird identification number); Age; Day (ordinal collection date); Year; Collection Site (name of public wetland from which bird was collected); food item Genera or Family; \% occurrence (percentage of birds containing each food item); and mean \% biomass of each food item.

Found at DOI: http://dx.doi.org/10.3996/072012JFWM-062.S1 (37 KB XLSX).

Table S2. Blue-winged teal Anas discors diet data (based on percent dry biomass) for birds collected during springs 2008 and 2009 in the Rainwater Basin of Nebraska. Data include Bird Number (individual bird identification number); Age; Day (ordinal collection date); Year; Collection Site (name of public wetland from which bird was collected); food item Genera or Family; \% occurrence (percentage of birds containing each food item); and mean \% biomass of each food item.

Found at DOI: http://dx.doi.org/10.3996/072012JFWM-062.S1 (37 KB XLSX).

Table S3. Use and availability data for mallard Anas platyrhynchos food items (based on percent dry mass) for birds collected during springs 2008 and 2009 in the Rainwater Basin of Nebraska. Data include Bird Number (individual bird identification number); Age; Day (ordinal collection date); Year; Wetland density (number of wetlands within a $10-\mathrm{km}$ radius of collection sites; Density category (categorical variable indicating "low" or "high" wetland density within $10 \mathrm{~km}$ of collection site); food item Genera or Family based on percent dry biomass of used and available food items.

Found at DOI: http://dx.doi.org/10.3996/072012JFWM-062.S1 (37 KB XLSX).

Table S4. Use and availability data for blue-winged teal Anas discors food items (based on percent dry mass) for birds collected during springs 2008 and 2009 in the Rainwater Basin of Nebraska. Data include Bird Number (individual bird identification number); Age; Day (ordinal collection date); Year; Wetland density (number of wetlands within a 10-km radius of collection sites; Density category (categorical variable indicating "low" or "high" wetland density within $10 \mathrm{~km}$ of collection site); food item Genera or Family based on percent dry biomass of used and available food items.

Found at DOI: http://dx.doi.org/10.3996/072012JFWM-062.S1 (37 KB XLSX).

Reference S1. Bishop AA, Vrtiska MP. 2008. Effects of the Wetlands Reserve Program on waterfowl carrying capacity in the Rainwater Basin Region of south-central Nebraska. Grand Island, Nebraska: U.S. Fish and Wildlife Service, Habitat and Population Evaluation Team.

Found at DOI: http://dx.doi.org/10.3996/072012-JFWM062.S2; also available at https://prod.nrcs.usda.gov/Internet/ FSE_DOCUMENTS/stelprdb1041753.pdf (1.2 MB PDF).

Reference S2. Carney SM. 1992. Species, age and sex identification of ducks using wing plumage. Washington, D.C.: U.S. Fish and Wildlife Service.

Found at DOI: http://dx.doi.org/10.3996/072012-JFWM062.S3; also available at http://digitalmedia.fws.gov/cdm/ref/ collection/document/id/1407 (11.4 MB PDF). 
Reference S3. Cowardin LM, Carter V, Golet FC, LaRoe ET. 1979. Classification of wetlands and deepwater habitats of the United States. Washington, D.C.: U.S. Fish and Wildlife Service, Office of Biological Science-79/31.

Found at DOI: http://dx.doi.org/10.3996/072012JFWM-062.S4; also available at http://library.fws.gov/ FWS-OBS/79_31.pdf (454 KB PDF).

\section{Acknowledgments}

We thank C. Ford and Boon for assisting with data collection and R. Grosse for technical assistance with GIS. We are also grateful to the U.S. Fish and Wildlife Service, Rainwater Basin Wetland Management District for providing access to their properties. This study was funded through the RWBJV, Nebraska Game and Parks Commission, and Arkansas Tech University. J. Fleskes, H. Hagy, D. Haukos, and T. Nupp provided helpful comments that improved this manuscript. The Missouri Cooperative Fish and Wildlife Research Unit is jointly sponsored by the Missouri Department of Conservation, the University of Missouri, the U.S. Fish and Wildlife Service, the U.S. Geological Survey, and the Wildlife Management Institute.

Any use of trade, firm, or product names is for descriptive purposes only and does not imply endorsement by the U.S. Government.

\section{References}

Alldredge JR, Griswold J. 2006. Design and analysis of resource selection studies for categorical resource variables. Journal of Wildlife Management 70:337-346.

Anderson JT, Smith LM, Haukos DA. 2000. Food selection and feather molt by nonbreeding American greenwinged teal in Texas playas. Journal of Wildlife Management 64:222-230.

Anteau MJ, Afton AD. 2004. Nutrient reserves of lesser scaup (Aythya affinis) during spring migration in the Mississippi flyway: a test of the spring condition hypothesis. Auk 121:917-929.

Arzel C, Elmberg J. 2004. Time use, foraging behaviour and microhabitat use in a temporary guild of springstaging dabbling ducks (Anas spp.). Ornis Fennica 81: 157-168.

Arzel, C, Elmberg J, Guillemain M. 2006. Ecology of spring migrating Anatidae: a review. Journal of Ornithology 147:167-184.

Bailey RO, Titman RD. 1984. Habitat use and feeding ecology of postbreeding redheads. Journal of Wildlife Management 48:1144-1155.

Barzen JA, Serie JR. 1990. Nutrient reserve dynamics of breeding canvasbacks. Auk 107:75-85.

Bety J, Gauthier G, Giroux JF. 2003. Body condition, migration and timing of reproduction in snow geese: a test of the condition-dependent model of optimal clutch size. American Naturalist 162:110-121.

Bishop AA, Vrtiska MP. 2008. Effects of the Wetland Reserve Program on waterfowl carrying capacity in the Rainwater Basin Region of south-central Nebraska.
Grand Island, Nebraska: U.S. Fish and Wildlife Service, Habitat and Population Evaluation Team (see Supplemental Material, Reference S1, http://dx.doi.org/10. 3996/072012-JFWM-062.S2); also available: https:// prod.nrcs.usda.gov/Internet/FSE_DOCUMENTS/stelprdb 1041753.pdf (February 2013).

Brasher MG, Steckel JD, Gates RJ. 2006. Energetic carrying capacity of actively and passively managed wetlands for migrating ducks in Ohio. Journal of Wildlife Management 71:2532-2541.

Brennan EK, Smith LM, Haukos DA, LaGrange TG. 2005. Short-term response of wetland birds to prescribed burning in Rainwater Basin wetlands. Wetlands 25: 667-674.

Brown M, Dinsmore JJ. 1986. Implications of marsh size and isolation for marsh bird management. Journal of Wildlife Management 50:392-397.

Callicutt JT, Hagy HM, Schummer ML. 2011. The food preference paradigm: a review of autumn-winter food use by North American dabbling ducks (1900-2009). Journal of Fish and Wildlife Management 2:29-40.

Carney SM. 1992. Species, age and sex identification of ducks using wing plumage. Washington, D.C.: U.S. Fish and Wildlife Service (see Supplemental Material, Reference S2, http://dx.doi.org/10.3996/072012-JFWM-062. S3); also available: http://digitalmedia.fws.gov/cdm/ref/ collection/document/id/1407 (February 2013).

Checkett JM, Drobney RD, Petrie MJ, Graber DA. 2002. True metabolizable energy of moist-soil seeds. Wildlife Society Bulletin 30:1113-1119.

Cowardin LM, Carter V, Golet FC, LaRoe ET. 1979. Classification of wetlands and deepwater habitats of the United States. Washington, D.C.: U.S. Fish and Wildlife Service, Office of Biological Science-79/31 (see Supplemental Material, Reference S3, http://dx.doi.org/ 10.3996/072012-JFWM-062.S4); also available: http:// library.fws.gov/FWS-OBS/79_31.pdf (February 2013).

Davis CA, Bidwell JR. 2008. Response of aquatic invertebrates to vegetation management and agriculture. Wetlands 28:793-805.

Davis, CA, Smith LM. 1998. Ecology and management of migrant shorebirds in the playa lakes region of Texas. Wildlife Monographs 140:1-45.

Delnicki D, Reinecke KJ. 1986. Mid-winter food use and body weight of mallards and wood ducks in Mississippi. Journal of Wildlife Management 50:43-51.

DeVries DH, Brook RW, Howerter DW, Anderson MG. 2008. Effects of spring body condition and age on reproductive performance in mallards (Anas platyrhynchos). Auk 125:618-628.

Dow H, Fredga S. 1984. Factors affecting reproductive output of the goldeneye duck (Bucephala clangula). Journal of Animal Ecology 53:679-692.

Drent RH. 1996. Energetic bottlenecks in the annual cycle of migratory wildfowl (Anatidae). Game and Wildlife Science 13:615-634.

Drilling N, Titman R, McKinney F. 2002. Mallard (Anas platyrhynchos). Account 658 in Poole A, editor. The 
birds of North America online. Ithaca, New York: Cornell Lab of Ornithology.

DuBowy JP. 1988. Waterfowl communities and seasonal environments: temporal variability in interspecific competition. Ecology 69:1439-1453.

Dzus EH, Clark RG. 1998. Brood survival and recruitment of mallards in relation to wetland density and hatching date. Auk 115:311-318.

Earth Resources Data Analysis System [ERDAS]. 1999. ERDAS field guide. Atlanta: ERDAS.

Fairbairn SE, Dinsmore JJ. 2001. Local and landscapelevel influences on wetland bird communities of the prairie pothole region of lowa, USA. Wetlands 21: 41-47.

Farmer AH, Parent AH. 1997. Effects of the landscape on shorebird movements at spring migration stopovers. Condor 99:698-707.

Gammonley JH. 1995. Spring feeding ecology of cinnamon teal in Arizona. Wilson Bulletin 107:64-72.

Gammonley JH, Heitmeyer ME. 1990. Behavior, body condition, and foods of buffleheads and lesser scaup during spring migration though the Klamath Basin, California. Wilson Bulletin 102:672-683.

Gauthier G. 1989. The effect of experience and timing on reproductive success of buffleheads. Auk 106:568576.

Gauthier G, Bedard J, Huot J, Bedard Y. 1992. Spring accumulation of fat by greater snow geese in two staging habitats. Condor 86:192-199.

Gloutney ML, Clark RG. 1991. The significance of body mass to female dabbling ducks during late incubation. Condor 93:811-816.

Gordon CC, Flake LD, Higgins KF. 1990. Aquatic invertebrates in the Rainwater Basin area of Nebraska. Prairie Naturalist 22:191-200.

Gruenhagen NM, Fredrickson LH. 1990. Food use of migratory female mallards in northwest Missouri. Journal of Wildlife Management 54:622-626.

Hagy HM, Kaminski RM. 2012. Winter waterbird and food dynamics in autumn-managed moist-soil wetlands in the Mississippi Alluvial Valley. Wildlife Society Bulletin 36:512-523.

Haukos DA, Smith LM. 2001. Temporal emergence patterns from seed banks of playa lakes. Wetlands 21:274-280.

Hepp GR, Kennamer RA, Harvey WF. 1989. Recruitment and natal philopatry of wood ducks. Ecology 70:897903.

Heitmeyer ME. 1988. Protein costs of the prebasic molt of female mallards. Condor 90:263-266.

Hitchcock AN. 2008. Diets of spring-migrating waterfowl in the Upper Mississippi River and Great Lakes Region. Master's thesis. Carbondale: Southern Illinois University.

Hoffman RD, Bookhout TA. 1985. Metabolizable energy of seeds consumed by ducks in Lake Erie marshes. Transactions of the North American Natural Resources Conference 50:557-565.
Hohman WL, Stark TM, Moore JL. 1996. Food availability and feeding preferences of breeding fulvous whistling-ducks in Louisiana rice fields. Wilson Bulletin 108:137-150.

Jeske CW. 1996. Migration strategies of North American Anatinae. Game and Wildlife Science 13:207-219.

Johnson DH. 1980. The comparison of usage and availability measurements for evaluating resource preference. Ecology 61:65-71.

Jorde DG, Krapu GL, Crawford RD. 1983. Feeding ecology of mallards wintering in Nebraska. Journal of Wildlife Management 47:1044-1053.

King JR. 1974. Seasonal allocation of time and energy resources in birds. Pages 4-85 in Paytner RA, editor. Avian energetics. Cambridge, Massachusetts: Nutall Ornithological Club.

Krapu GL. 1974. Feeding ecology of pintail hens during reproduction. Auk 91:278-290.

Krapu GL. 1981. The role of nutrient reserves in mallard reproduction. Auk 98:29-38.

Krapu GL, Reinecke KJ. 1992. Foraging ecology and nutrition. Pages 1-29 in Batt BDJ, Afton AD, Anderson MG, Ankney $C D$, Johnson $D H$, Kadlec JA, Krapu GL, editors. Ecology and management of breeding waterfowl. Minneapolis: University of Minnesota Press.

Kross J, Kaminski RM, Reinecke KJ, Penny EJ, Pearse AT. 2008. Moist-soil seed abundance in managed wetlands in the Mississippi Alluvial Valley. Journal of Wildlife Management 72:707-714.

LaGrange TG. 2005. Guide to Nebraska's wetlands and their conservation needs. Lincoln: Nebraska Game and Parks Commission. Available: http://outdoornebraska. ne.gov/wildlife/programs/wetlands/pdf/wetlandsguide. pdf (February 2013).

LaGrange TG, Dinsmore JJ. 1988. Nutrient reserve dynamics of female mallards during spring migration through central lowa. Pages 287-297 in Weller MW, editor. Waterfowl in winter. Minneapolis: University of Minnesota Press.

Legagneux P, Duhart M, Schricke V. 2007. Seeds consumed by waterfowl in winter: a review of methods and a new web-based photographic atlas for seed identification. Journal of Ornithology 148:537-541.

Manley SW, Hohman WL, Moore JL, Richard D. 1992. Food preferences of spring migrating blue-winged teal in southwestern Louisiana. Proceedings of the Annual Conference of the Southeastern Association of Fish and Wildlife Agencies 46:46-56.

Markkola J, Niemela M, Rytkonen S. 2003. Diet selection of lesser white-fronted geese Anser erythropus at a spring staging area. Ecography 26:705-714.

Martin AC, Barkley WD. 1973. Seed identification manual. 2nd edition. Berkeley: University of California Press.

McLandress MR, Raveling DG. 1981. Changes in diet and body condition of Canada geese before spring migration. Auk 98:65-79.

Merritt RW, Cummins KW, editors. 1996. An introduction to the aquatic insects of North America. Dubuque, lowa: Kendall/Hunt. 
Miller MR, Burns EG, Wickland BE, Eadie JM. 2009. Diet and body mass of wintering ducks in adjacent brackish and freshwater habitats. Waterbirds 32:374387.

Murkin HR, RossLCM. 1999. Northern prairie marshes (Delta Marsh, Manitoba): I. Macroinvertebrate responses to a simulated wet/dry cycle. Pages 543-69 in Batzer DP, Rader RB, Wissinger SA, editors. Invertebrates in freshwater wetlands of North America: ecology and management. New York: John Wiley \& Sons.

Myers JP. 1983. Conservation of migrating shorebirds: staging areas, geographical bottlenecks and regional movements. American Birds 37:23-25.

Olmstead, VH, Webb EB, Johnson RW. 2013. Moist-soil seed biomass and species richness on Wetland Reserve Program easements in the Mississippi Alluvial Valley. Wetlands 33:197-206.

Pattenden RK, Boag DA. 1989. Effects of body mass on courtship, pairing, and reproduction in captive mallards. Canadian Journal of Zoology 67:495-501.

Pearse AT, Kaminski RM, Reinecke KJ, Dinsmore SJ. 2012. Local and landscape associations between wintering dabbling ducks and wetland complexes in Mississippi. Wetlands 32:859-869.

Pearse AT, Krapu GL, Cox RR, Davis BE. 2011. Springmigration ecology of northern pintails in south-central Nebraska. Waterbirds 34:10-18.

Pennak RW. 1989. Freshwater invertebrates of North America. New York: John Wiley \& Sons.

Reinecke KJ, Owen RB. 1980. Food use and nutrition of black ducks nesting in Maine. Journal of Wildlife Management 44:549-558.

Rowher FC, Johnson WP, Loos ER. 2002. Blue-winged teal (Anas discors). Account 625 in Poole A, editor. The birds of North America online. Ithaca, New York: Cornell Lab of Ornithology.

Smith BJ, Higgins KF. 1990. Avian cholera and temporal changes in wetland numbers and densities in Nebraska's Rainwater Basin area. Wetlands 10:1-5.

Smith LM. 2003. Playas of the Great Plains. Austin: University of Texas Press.

Swanson GA, Krapu GL, Bartonek JC, Serie JR, Johnson $\mathrm{DH} .1974 \mathrm{a}$. Advantages in mathematically weighting waterfowl food habits data. Journal of Wildlife Management 38:302-307.

Swanson GA, Meyer MI. 1977. Impacts of fluctuating water levels on feeding ecology of breeding bluewinged teal. Journal of Wildlife Management 41:426433.
Swanson, GA, Meyer MI, Adomaitis VA. 1985. Foods consumed by breeding mallards on wetlands in south-central North Dakota. Journal of Wildlife Management 49:197-203.

Swanson GA, Meyer MI, Serie JR. 1974b. Feeding ecology of breeding blue-winged teals. Journal of Wildlife Management 38:396-407.

Taft OW, Haig SM. 2006. Landscape context mediates influence of local food abundance on wetland use by wintering shorebirds in an agricultural valley. Biological Conservation 128:298-307.

Taylor TS. 1978. Spring foods of migrating blue-winged teals on seasonally flooded impoundments. Journal of Wildlife Management 42:900-903.

Tidwell PR. 2010. Effects of wetland density and area on nutrient reserves, lipid acquisition and diet of dabbling ducks migrating through the Rainwater Basin of Nebraska. Master's thesis. Russellville: Arkansas Tech University.

U.S. Department of Agriculture. 2009. The PLANTS database. National Plant Data Team, Greensboro, North Carolina: National Plant Data Team. Available: http://plants.usda.gov (Accessed July 2009).

U.S. Fish and Wildlife Service. 2007. Final Environmental Impact Statement: light goose management. Washington, D.C.: U.S. Fish and Wildlife Service. Available: http://www.fws.gov/migratorybirds/CurrentBirdlssues/ Management/snowgse/FinalEIS2007/Light\%20goose\% 20EIS.pdf (Accessed March 2013).

Waller RA, Duncan DB. 1969. A Bayes' rule for the symmetric multiple comparisons problem. Journal of the American Statistical Association 64:1484-1503.

Weaver JE, Bruner WE. 1954. Nature and place of transition from true prairie to mixed prairie. Ecology 35:117-126.

Webb EB, Smith LM, Vrtiska MP, LaGrange TG. 2010. Effects of local and landscape variables on wetland bird habitat use during migration through the Rainwater Basin. Journal of Wildlife Management 74: 109-119.

Webb EB, Smith LM, Vrtiska MP, LaGrange TG. 2011. Factors influencing behavior of wetland birds in the Rainwater Basin during spring migration. Waterbirds 34:457-467.

Williams BK, Koneff MD, Smith DA. 1999. Evaluation of water conservation under the North American Waterfowl Management Plan. Journal of Wildlife Management 63:417-440. 